\title{
ANALISIS KELAYAKAN PENCADANGAN KAWASAN SHRIMP ECO-FARMING DI KABUPATEN PINRANG
}

(Analysis of Feasibility of Area Determination Shrimp Eco-Farming in Pinrang District)

\author{
oleh: \\ Sitti Marhamah Syam¹, M.Hattah Fattah ${ }^{2}$, Asbar $^{3}$ \\ 1) Mahasiswa PS Manajemen Pesisir dan Teknologi Kelautan PPS UMI \\ 2) Dosen PS Budidaya Perairan FPIK UMI \\ 3) Dosen PS Ilmu Kelautan FPIK UMI
}

Korespondensi: marhamahpinrang@gmail.com

Diterima: tanggal 20 Sepetember 2018; Disetujui 30 November 2018

\begin{abstract}
The increasing global market demand is an opportunity for the development and improvement of the eco-shrimp category of Penaeus monodon. The global market demands for producing eco-shrimp shrimp and the application of EAA (Ecology Aquaculture Area), initiated the establishment of the Shrimp Eco-farming Park area in Pinrang Regency. The Minapolitan Lowita area in Lanrisang Subdistrict is an expansion of the Minapolitan Lowita Area in Suppa Subdistrict, agreed upon as a development area for tiger shrimp (Penaeus monodon) oriented to the Shrimp Eco-farming Park in Pinrang Regency. This study aims to analyze the level of the feasibility of ponds in Lanrisang District to be reserved for the Shrimp Eco-farming Park Region of Pinrang Regency. The study was conducted in Lanrisang District, Pinrang Regency from April 2017 to March 2018. The research method was by observation and analysis of test samples. The number of test samples was 12 samples, taken at 12 locations during the rainy season and dry season. The parameters measured were aquatic biophysics (water quality, soil quality, topography, rainfall, and tides) during the rainy season and dry season. Feasibility analysis uses a weighting system and suitability parameter scores. The results showed: the level of the feasibility of the pond was very suitable during the rainy season (8.45) and the level of the feasibility of the pond was suitable in the dry season (7.15).
\end{abstract}

Keyword: Feasibility Analysis, Pinrang Regency, Shrimp Eco-farming Area.

\begin{abstract}
ABSTRAK.
Permintaan pasar global yang terus meningkat menjadi peluang bagi pengembangan dan peningkatan budidaya udang windu (Penaeus monodon) kategori eco-shrimp. Tuntutan pasar global menghasilkan udang jenis eco-shrimp dan penerapan EAA (Ecology Aquakultur Area), menginisiasi pembentukan kawasan Shrimp Eco-farming Park di Kabupaten Pinrang. Kawasan Minapolitan Lowita di Kecamatan Lanrisang merupakan perluasan area Kawasan Minapolitan Lowita di Kecamatan Suppa, disepakati sebagai kawasan pengembangan udang windu (Penaeus monodon) berorientasi Shrimp Ecofarming Park di Kabupaten Pinrang. Penelitian ini bertujuan menganalisis tingkat kelayakan tambak di Kecamatan Lanrisang untuk dicadangkan menjadi Kawasan Shrimp Eco-farming Park Kabupaten Pinrang. Penelitian dilaksanakan di Kecamatan Lanrisang Kabupaten Pinrang pada bulan April 2017 sampai dengan bulan Maret 2018. Metode penelitian secara observasi dan analisis sampel uji. Jumlah sampel uji sebanyak 12 sampel, diambil pada 12 lokasi pada musim hujan dan musim kemarau.
\end{abstract}


Parameter yang diukur adalah biofisik perairan (kualitas air, kualitas tanah, topografi, curah hujan dan pasang surut) pada musim hujan dan musim kemarau. Analisis kelayakan menggunakan sistem pembobotan dan skor parameter kesesuain. Hasil penelitian menunjukkan : tingkat kelayakan tambak sangat sesuai pada musim hujan $(8,45)$ dan tingkat kelayakan tambak sesuai pada musim kemarau $(7,15)$.

\section{Kata kunci: Analisis Kelayakan, Kabupaten Pinrang, Kawasan Shrimp Eco-farming,}

\section{PENDAHULUAN}

Peningkatan populasi penduduk dunia berdampak terhadap peningkatan konsumsi produk perikanan. Menurut Silva (2011), peningkatan populasi penduduk menyebabkan peningkatan konsumsi produk perikanan global. Permintaan pasar ekspor terhadap produk perikanan yang terus meningkat menjadi peluang bagi pengembangan budidaya dan peningkatan produk perikanan budidaya. Faktor ketertelusuran penggunaan input produksi dan manajemen produksi (tracebility) dan pertimbangan keamanan pangan (food safety) menjadi dasar utama penilaian kualitas produk perikanan yang diperdagangkan pada pasar internasional. Pengembangan udang windu menghadapi tekanan dalam bentuk ekspansi perluasan areal budidaya udang vaname (Litopenaeus vannamei) secara masif. Budidaya udang vaname yang sebelumya dimaksudkan sebagai pengaman produksi udang nasional setelah udang windu terjangkit wabah khususnya white spote syndrome virus (WSSV) dan Vibrio harvey (Fattah et al., 2013; Rukyani, 1999).

Berdasarkan kondisi tersebut, pengembangan udang windu jenis ecoshrimp harus dilakukan secara inklusif. Pengembangan budidaya udang windu jenis eco-shrimp memerlukan kawasan yang dipersiapkan secara khusus untuk budidaya udang windu jenis eco-shrimp dengan sistem pengelolaan area budidaya yang spesifik (FAO, 2017). Kabupaten Pinrang telah ditetapkan menjadi sentra pengembangan budidaya udang windu nasional. Berdasarkan hasil pertemuan multi stakeholders pada tahun 2016, disepakati kawasan replikasi pengembangan udang windu berada pada areal pertambakan di Kecamatan Lanrisang Kabupaten Pinrang. Pengembangan kawasan perikanan budidaya di Kawasan Minapolitan Kabupaten Pinrang turut memperhatikan agenda pembangunan berkelanjutan (sustainable development), yang disebut SDGs (sustainable development goals) yang disepakati oleh 192 (UNDP, 2015. Menurut Klein (2012), Eco-farming didefenisikan sebagai sebuah sistem pengendalian gulma dan pengelolaan residu tanaman, sepanjang rotasi panen dengan meminimalkan penggunaan lahan untuk mengurangi erosi tanah dan biaya produksi sambil meningkatkan pengendalian gulma, infiltrasi air, konservasi kelembaban, dan hasil panen. Shrimp Eco-farming diartikan sebagai suatu sistem budidaya udang berbasis aquaculture management area (AMA) dengan sasaran menghasilkan produk udang jenis eco-shrimp dengan mengaplikasikan sistem budidaya dan input produksi ramah lingkungan (ecofriendly) yang mendorong terciptanya 
harmoni sosial dan peningkatan kesejahteraan para pelaku.

Pengembangan Shrimp Eco-farming Park Kabupaten Pinrang dirancang khusus untuk meningkatkan produktivitas udang windu dalam kondisi masih masifnya infeksi patogen khususnya jenis WSSV dan $V$. harvey. Pengembangan Shrimp Eco-farming Park Kabupaten Pinrang dicadangkan di Kecamatan Lanrisang dan menjadi kawasan pengembangan baru sebagai perluasan dari Kawasan Minapolitan yang terletak di Kecamatan Suppa. Olehnya itu, sebelum Kecamatan Lanrisang dicadangkan sebagai Kawasan Shrimp Eco-farming Park Kabupaten Pinrang perlu dilakukan kajian mengenai analisis tingkat kelayakan tambak di Kecamatan Lanrisang.

\section{METODE PENELITIAN}

Penelitian dilaksanakan pada bulan April 2017 s/d Pebruari 2018 di

Kecamatan Lanrisang Kabupaten Pinrang. Tahapan yang dilakukan dalam penelitian ini:

- Observasi : Identifikasi kelayakan calon lokasi yang akan dicadangkan sebagai kawasan Shrimp Eco -farming Park di Kabupaten Pinrang serta aktivitas yang berlangsung di dalam kawasan

- Pengambilan sampel uji : Dilakukan pada duabelas titik lokasi yang ditunjukkan pada gambar 1, pada musim hujan dan musim kemarau.

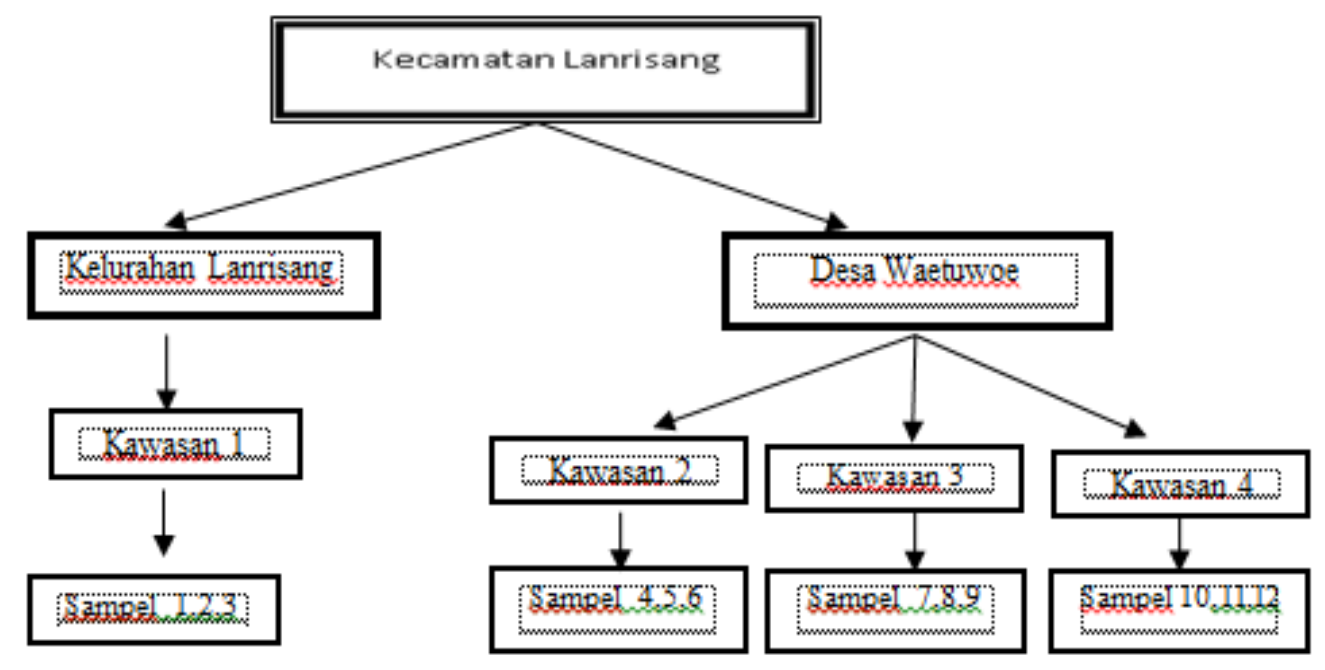

Gambar 1. Skema pengambilan sampel

- Analisis sampel: Analisis sampel kelayakan tambak pada musim hujan berdasarkan parameter data kelayakan biofisik (kualitas air, kualitas tanah, topografi, curah hujan, pasang surut) dan musim kemarau berdasarkan pembobotan dan skor parameter kesesuaian pada Tabel 1 dan 2

- Analisis data: hasil analisis sampel selanjutnya dianalisis tingkat 
Tabel 1. Matriks Pembobotan dan Pemberian Skor Parameter Kesesuaian Budidaya Tambak

\begin{tabular}{|c|c|c|c|c|c|c|c|c|c|}
\hline \multirow{2}{*}{ Parameter } & \multirow{2}{*}{ Bobot } & \multicolumn{8}{|c|}{ Kategori dan Skor } \\
\hline & & S1 & Skor & $\mathrm{S} 2$ & Skor & S3 & Skor & $\mathrm{N}$ & Skor \\
\hline $\begin{array}{l}\text { Kemiringan Lereng } \\
(\%)\end{array}$ & 0,20 & $0-3$ & 4 & $3-6$ & 3 & $6-9$ & 2 & $>9$ & 1 \\
\hline Jarak dari Pantai $(\mathrm{m})$ & 0,10 & $200-300$ & 4 & $300-400$ & 3 & $<200$ & 2 & $>4000$ & 1 \\
\hline $\begin{array}{l}\text { Jarak dari sungai } \\
(\mathrm{m})\end{array}$ & 0,10 & $0-1.000$ & 4 & $\begin{array}{l}1.000- \\
2.000\end{array}$ & 3 & $2.000-3.000$ & 2 & - & 1 \\
\hline Jenis Tanah & 0,10 & $\begin{array}{l}\text { Aluvial } \\
\text { Pantai }\end{array}$ & 4 & $\begin{array}{c}\text { Alluvial } \\
\text { Hidro-mof }\end{array}$ & 3 & $\begin{array}{c}\text { Regosol, } \\
\text { Gleihu-mus }\end{array}$ & 2 & $\begin{array}{c}\text { Regosol, } \\
\text { Gleihu-mus }\end{array}$ & 1 \\
\hline Ketinggian(m) & 0,15 & $0-3$ & 4 & $3-6$ & 3 & $6-9$ & 2 & $>9$ & 1 \\
\hline Drainase & 0,10 & $\begin{array}{l}\text { Terge- } \\
\text { nang }\end{array}$ & 4 & $\begin{array}{l}\text { Terge- } \\
\text { nang }\end{array}$ & 3 & $\begin{array}{c}\text { Tidak } \\
\text { Terge-nang }\end{array}$ & 2 & $\begin{array}{c}\text { Tidak } \\
\text { Terge-nang }\end{array}$ & 1 \\
\hline Geologi & 0,10 & $\begin{array}{c}\text { Sedemen } \\
\text { lepas }\end{array}$ & 4 & $\begin{array}{c}\text { Sedemen } \\
\text { lepas }\end{array}$ & 3 & $\begin{array}{c}\text { Sedemen } \\
\text { padu }\end{array}$ & 2 & $\begin{array}{c}\text { Sedemen } \\
\text { padu }\end{array}$ & 1 \\
\hline Salinitas (ppt) & 0,3 & $12-20$ & 4 & $20-30$ & 3 & $\begin{array}{l}5-12 \\
30-45\end{array}$ & 2 & $<5 ;>45$ & 1 \\
\hline Suhu $\left({ }^{\circ} \mathrm{C}\right)$ & 0,3 & $25-32$ & 4 & $23-25$ & 3 & $32-34$ & 2 & $0-23$ & 1 \\
\hline $\begin{array}{l}\text { Oksigen Terlarut } \\
(\mathrm{mg} / \mathrm{l})\end{array}$ & 0,3 & $6-7$ & 4 & $3-6$ & 3 & $1-3$ & 2 & $<1 ;<8$ & 1 \\
\hline $\mathrm{pH}$ & 0,3 & $8,1-8,7$ & 4 & $\begin{array}{l}7,6-8,0 \\
6,1-7,6\end{array}$ & 3 & $\begin{array}{c}8,8-9,5 \\
4,0-4,5\end{array}$ & 2 & $\begin{array}{l}9,6-11,0 \\
<4,0\end{array}$ & 1 \\
\hline Posfat $\left(\mathrm{PO}_{4}\right)$ & 0,1 & 0 & 4 & $0,1-0,25$ & 3 & $0,26-0.45$ & 2 & $>0,45$ & 1 \\
\hline Amoniak $\left(\mathrm{NH}_{3}\right)$ & 0,1 & 0 & 4 & $0,1-0,25$ & 3 & $0,26-0.45$ & 2 & $>0,45$ & 1 \\
\hline Nitrit $\left(\mathrm{NO}^{2}\right)(\mathrm{mg} / \mathrm{l})$ & 0.05 & 0 & 4 & $0,1-0,25$ & 3 & $0,26-0.45$ & 2 & $>0,45$ & 1 \\
\hline
\end{tabular}

Penentuan skor klas kesesuaian lahan tambak mengacu pada Tabel 2.

Tabel 2. Skor Klas Kesesuaian Lahan Tambak

\begin{tabular}{clc}
\hline No. & \multicolumn{1}{c}{ Klas Kesesuaian } & Skor $\mathbf{( \% )}$ \\
\hline 1. & S1 (Sangat Sesuai) & $85-100$ \\
2. & S2 (Cukup Sesuai) & $60-84$ \\
3. & S3 (Sesuai Marjinal/Hampir Sesuai) & $40-64$ \\
4. & N1 (Tidak Sesuai Saat ini) & $1-39$ \\
\hline
\end{tabular}

\section{HASIL DAN PEMBAHASAN}

Kecamatan Lanrisang adalah salah satu kecamatan pesisir di Kabupaten Pinrang Provinsi Sulawesi Selatan. Secara geografis Kecamatan Lanrisang terletak antara $3^{0} 53^{\prime} 8.4^{\prime \prime}$ LS $-4^{0} 10^{\prime} 30^{\prime \prime}$ LS, $119^{\circ} 34^{\prime} 39^{\prime \prime}$ BT - 19047’39”. Secara administrasi Kecamatan Lanrisang berbatasan .

Sebelah Utara $\quad$ : Kecamatan Mattiro Sompe.
Sebelah Timur $\quad$ : Kecamatan Mattiro

Bulu

Sebelah Selatan : Kecamatan Suppa

Sebelah Barat : Selat Makassar

Luas Kecamatan Lanrisang 73,01 $\mathrm{km}^{2}$ yang memiliki 7 Desa/kelurahan yaitu Kelurahan Lanrisang, Desa Lerang, Desa Samaulue, Desa Mallongi-longi, Desa Ammasangan, Desa Barangpalie dan Desa Waetuoe dengan jumlah penduduk 17.842. Kecamatan Lanrisang memiliki 2 Desa/Kelurahan pesisir yaitu Kelurahan 
Lanrisang dan Desa Waetuoe atau $50 \%$ dari luas Kecamatan Lanrisang. Luas wilayah Kelurahan Lanrisang adalah 18,27 $\mathrm{km}^{2}$ yang terletak lebih kurang $19 \mathrm{~km}$ dari Ibu Kota Kabupaten Pinrang, secara administratif terdiri atas 3 lingkungan, 5 RW dan 10 RT. Luas wilayah Desa Waetuoe $17,89 \mathrm{~km}^{2}$ yang terletak lebih kurang 19 km dari ibu Kota Kabupaten Pinrang, secara administrasi terdiri atas 3 Dusun, 4 RW dan 8 RT (BPS Kabupaten Pinrang, 2017).
Tingkat kelayakan tambak dibedakan atas kelayakan pada musim hujan dan kelayakan pada pada musim kemarau. Tingkat kelayakan pada masingmasing musim diuraikan sebagai berikut:

1. Tingkat Kelayakan Tambak pada Musim Hujan

Hasil analisis pengukuran parameter fisik dan kualitas air tingkat kelayakan pada musim hujan disajikan pada Tabel 3.

Tabel 3. Tingkat Kelayakan Tambak pada Musim Hujan

\begin{tabular}{lcccc}
\hline \multicolumn{1}{c}{ Parameter } & Bobot & Hasil Pengukuran & Skor & Nilai \\
\hline Kemiringan Lereng (\%) & 0,20 & 0,03 & 4 & 0,80 \\
Jarak dari Pantai (m) & 0,10 & 1000 & 2 & 0,20 \\
Jarak dari sungai (m) & 0,10 & $300-1600$ & 3 & 0,30 \\
Jenis Tanah & 0,10 & Aluvial Pantai & 4 & 0.40 \\
Ketinggian(m) & 0,15 & $1,2-1,4$ & 4 & 0,60 \\
Drainase & 0,10 & Tergenang & 4 & 0,40 \\
Geologi & 0,10 & Sedimen lepas & 4 & 0,40 \\
Salinitas (ppt) & 0,3 & $7-22$ & 2 & 0,60 \\
Suhu $\left({ }^{\circ} \mathrm{C}\right)$ & 0,3 & $27-31$ & 4 & 1,20 \\
Oksigen terlarut (mg/l) & 0,3 & $5,4-8,9$ & 4 & 1,20 \\
pH & 0,3 & $6,14-9,73$ & 4 & 1,20 \\
Posfat $\left(\mathrm{PO}_{4}\right)$ & 0,1 & $0,05-0,1$ & 3 & 0,30 \\
Amoniak $(\mathrm{NH})$ & 0,1 & $0,05-0,1$ & 3 & 0,30 \\
Nitrit $\left(\mathrm{NO}_{2}\right)(\mathrm{mg} / \mathrm{l})$ & 0.05 & $0,05-0,1$ & 3 & 0,15 \\
& 2,50 & & & 8,45 \\
\hline
\end{tabular}

Sumber : Data Primer Setelah Diolah , 2018.

Berdasarkan nilai pembobotan dan pengharkatan dari parameter di atas, maka dapat ditentukan nilai kelas kesesuaian lahan yaitu : 1) Sangat sesuai (S1):8,17$10,00 ; 2)$ Sangat sesuai (S1) : 8,17-10,00; 3) Sesuai Bersyarat (S3): 4,39-6,27; dan 4) tidak sesuai permanen (N): 2,50-4,38.

Berdasarkan nilai pembobotan dan pengharkatan parameter pada Tabel 3 ditetapkan nilai kelas kesesuaian lahan pada Musim Hujan $(8,45)$ berada pada
Kategori Sangat Sesuai (S1). Sejumlah parameter tidak mencapai skor maksimal yakni jarak dari pantai $(1.000 \mathrm{~m})$, jarak dari sungai (300 -1.600 m), salinitas (7-22 ppt), posfat $(0,05-0,1 \mathrm{ppm})$, amoniak $(0,05-0,1 \mathrm{ppm})$, dan nitrit $(0,05-0,1$ ppm). $(0,05-0,1 \mathrm{ppm})$.

Parameter jarak dari pantai dan jarak dari sungai bersifat permanen dan berdampak pada dinamika kualitas air terutama salinitas. Kawasan tambak di 
Kelurahan Lanrisang berada pada DAS Sungai Sumpang Saddang sehingga mendapatkan pasokan air tawar yang berlimpah pada Musim Hujan. Salinitas pada Musim Hujan cenderung rendah (13$17 \mathrm{ppt}$ ) tetapi tetap pada kisaran optimum $(12-20 \mathrm{ppt})$. Tambak yang berada pada DAS Salopokkoe pada Musim Hujan berada pada kisaran $(7-15 \mathrm{ppt})$ atau cenderung lebih rendah dari kisaran salinitas ideal. Salinitas pada kawasan tambak di Desa Waetuwoe yang relatif jauh dari jangkauan pengaruh aliran sungai cenderung lebih tingggi $(12-22$ ppt) dari kisaran salinitas optimum. Kadar posfat (0,05-1), amoniak (0,05-1), dan nitrit $(0,05-1)$ pada seluruh kawasan pertambakan lebih tinggi dari kisaran yang dianjurkan. Pengambilan sampel dilakukan setelah beberapa periode dilakukan aplikasi pupuk organik berkontribusi terhadap peningkatan kadar posfat, amoniak, dan nitrit.

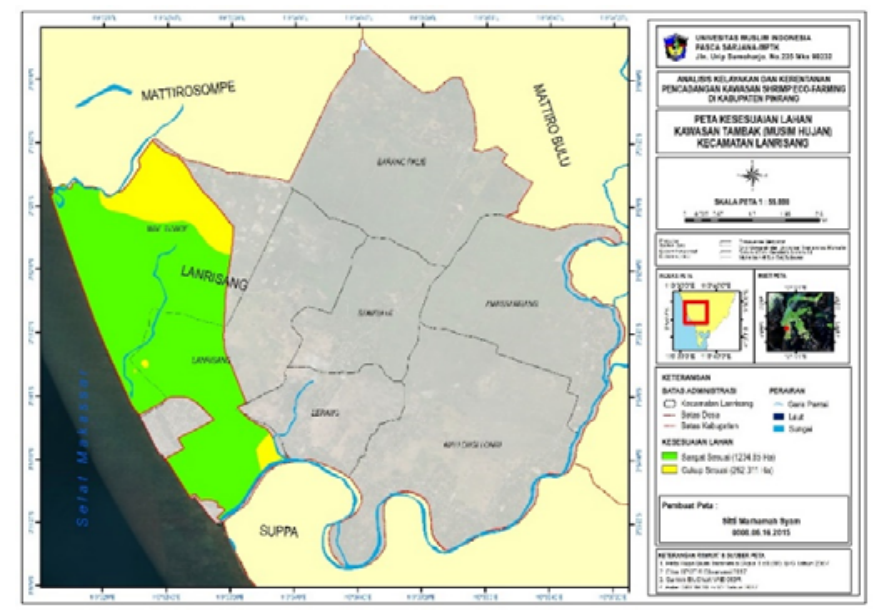

Gambar 2. Peta Kesesuaian Lahan pada Musim Hujan Pencadangan Kawasan Shrimp

Eco-farming Kabupaten Pinrang

2. Tingkat Kelayakan Tambak pada $1.600 \mathrm{~m})$, salinitas (9-39 ppt), suhu (22,7 Musim Kemarau $\left.38{ }^{\circ} \mathrm{C}\right)$, ph $(7,5-9,88)$, posfat $(0,05-0,1$

Tingkat kelayakan tambak pada ppm), amoniak $(0-0,05 \mathrm{ppm})$, dan nitrit musim kemarau di Kecamatan Lanrisang $(0-0,05$ ppm).

Kabupaten Pinrang disajikan pada Tabel 5. Nilai pembobotan dan pengharkatan parameter pada Tabel 10 menghasilkan nilai kelas kesesuaian lahan pada Musim Kemarau $(7,15)$ berada pada Kategori Sesuai (S2). Sejumlah parameter tidak mencapai skor maksimal yakni jarak dari pantai $(1.000 \mathrm{~m})$, jarak dari sungai (300 - 
Tabel 5 . Tingkat Kelayakan Tambak pada Musim Kemarau di Kecamatan Lanrisang Kabupaten Pinrang

\begin{tabular}{|c|c|c|c|c|}
\hline Parameter & Bobot & Hasil Pengukuran & Skor & Nilai \\
\hline Kemiringan Lereng (\%) & 0,20 & 0,03 & 4 & 0,80 \\
\hline Jarak dari Pantai (m) & 0,10 & 1000 & 2 & 0,20 \\
\hline Jarak dari sungai (m) & 0,10 & $300-1600$ & 3 & 0,30 \\
\hline Jenis Tanah & 0,10 & Aluvial Pantai & 4 & 0.40 \\
\hline Ketinggian(m) & 0,15 & $1,2-1,4$ & 4 & 0,60 \\
\hline Drainase & 0,10 & Tergenang & 4 & 0,40 \\
\hline Geologi & 0,10 & Sedimen lepas & 4 & 0,40 \\
\hline Salinitas (ppt) & 0,3 & $9-39$ & 2 & 0,60 \\
\hline Suhu $\left({ }^{\circ} \mathrm{C}\right)$ & 0,3 & $22,7-38$ & 2 & 0,60 \\
\hline Oksigen terlarut (mg/l) & 0,3 & $4,7-14,4$ & 4 & 1,20 \\
\hline $\mathrm{pH}$ & 0,3 & $7,50-9,88$ & 3 & 0,90 \\
\hline Posfat $\left(\mathrm{PO}_{4}\right)$ & 0,1 & $0,05-0,1$ & 3 & 0,30 \\
\hline Amoniak $\left(\mathrm{NH}_{3}\right)$ & 0,1 & $0-0,05$ & 3 & 0,30 \\
\hline \multirow{2}{*}{ Nitrit $\left(\mathrm{NO}_{2}\right)(\mathrm{mg} / \mathrm{l})$} & 0.05 & $0-0,05$ & 3 & 0,15 \\
\hline & 2,50 & & & 7,15 \\
\hline
\end{tabular}

Sumber : Data Primer Setelah Diolah, 2018

Kawasan tambak di Kelurahan Lanrisang mendapat pasokan air tawar dari Sungai Jampue secara berkesinambungan sehingga suhu $(22,7-23,6 \mathrm{ppt})$ tetap berada pada kisaran optimum. Pasokan air tawar secara berkesinambungan dari DAS Sumpang Saddang menyebabkan kisaran salinitas $(8-16 \mathrm{ppt})$ berada diluar kisaran optimum. Anomali iklim sedang berlangsung sejak tahun 2015 pada kawasan lokasi penelitian menyebabkan perbedaan musim menjadi relatif. Pada Musim Kemarau masih berpeluang terjadi hujan. Kisaran suhu $(24,4$ - 26,8), pada DAS Salopokkoe masih berada pada kisaran optimum. Pasokan air tawar yang terbatas menyebabkan terjadi peningkatan salinitas (14 - 35 ppt) yang melebihi kadar optimum. Dinamika kualitas air pada
Musim Kemarau cenderung memicu peningkatan $\mathrm{pH}$ media $(7,50-9,88)$ yang lebih tinggi dari $\mathrm{pH}$ optimum.

Dinamika kualitas air selama penelitian disajikan pada Tabel 11 dan Gambar 3. Parameter suhu dan salinitas mengalami fluktuasi pada Musim Hujan dan Musim Kemarau. Parameter posfat, amonia, nitrat, dan $\mathrm{pH}$ cenderung stabil pada Musim Hujan dan Musim Kemarau. Suhu pada Musim Kemarau $(26,66 \pm 2,34$ $\left.{ }^{\circ} \mathrm{C}\right)$ cenderung lebih fluktuatif dibandingkan dengan Musim Hujan $\left(29,04 \pm 0,69{ }^{\circ} \mathrm{C}\right)$. Kondisi yang sama ditemukan pada parameter salinitas. Salinitas air tambak pada Musim Kemarau. $\quad(22,91 \pm 10,94 \quad$ ppt $)$ lebih fluktuatif dibandingkan pada Musim Hujan $(13,67 \pm 4,74$ ppt). 


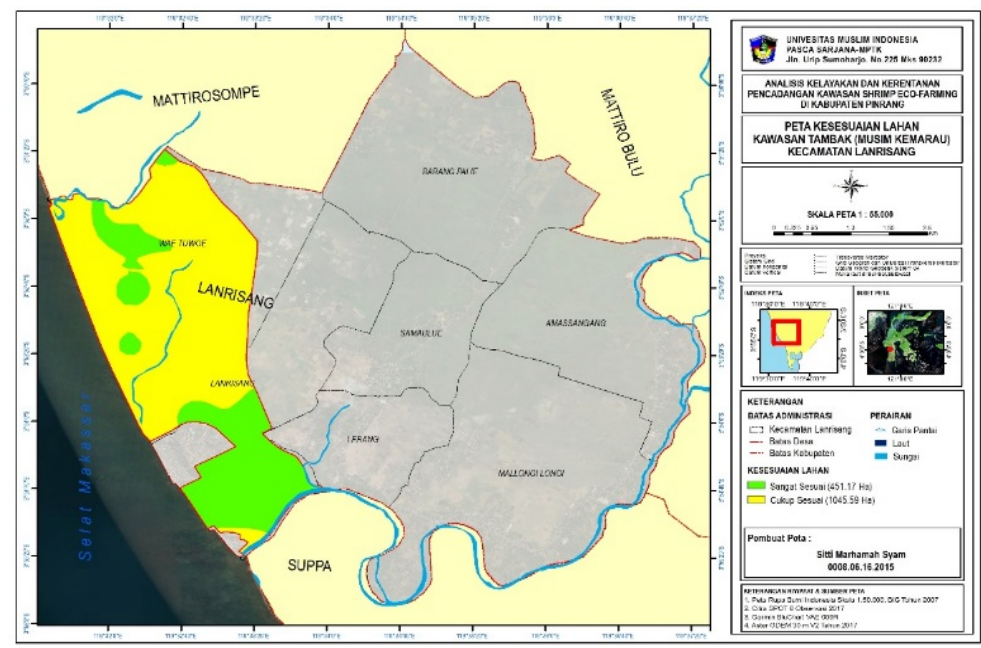

Gambar 3. Peta Kesesuaian Lahan pada Musim Kemarau di lokasi Pencadangan Kawasan Shrimp Eco-farming di Kabupaten Pinrang.

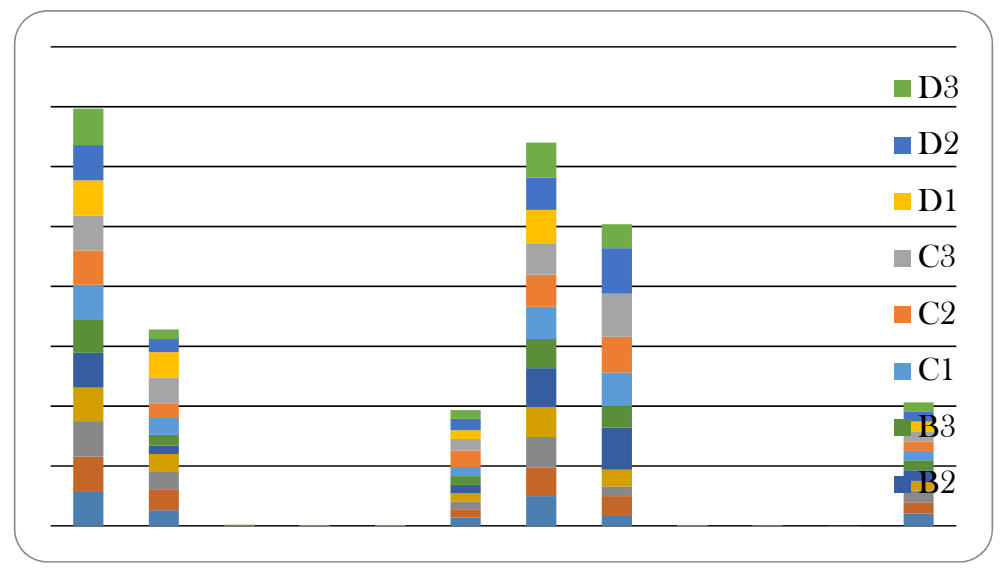

Gambar 4. Dinamika Kualitas Air pada Kawasan Pencadangan Shrimp Eco-farming Kabupaten Pinrang

Suhu pada Musim Hujan dan Musim Kemarau masih berada kisaran optimum. Salinitas pada Musim Hujan dan Kemarau telah berada diluar kisaran optimum sehingga menjadi penyebab utama menurunnya tingkat kelayakan nilai kelas kesesuaian lahan pada Musim Hujan dan Musim Kemarau menjadi Kategori Sesuai (S2) berdasarkan (Permen KP No 75 tahun 2016).

\section{KESIMPULAN}

Tingkat kelayakan tambak di Kecamatan Lanrisang untuk dicadangkan menjadi Kawasan Shrimp Eco-farming Park di Kabupaten Pinrang adalah sangat sesuai pada musim hujan $(8,45)$ dan tingkat kelayakan tambak sesuai pada musim kemarau $(7,15)$. 


\section{SARAN}

Konsistensi tingkat kelayakan lahan pada Musim Kemarau melalui perbaikan fungsi saluran tambak dan sungai dalam memasok air baku secara berkesinambungan untuk mempertahankan stabilitas suhu dan salinitas serta kelayakan media budidaya untuk mendukung peningkatan pertumbuhan dan kelangsungan hidup

\section{UCAPAN TERIMA KASIH}

Tulisan ini merupakan bagian dari penelitian tesis pada program studi Manajemen Pesisir dan Teknologi Kelautan dan penulis mengucapkan terima kasih kepada Pemerintah Kabupaten Pinrang yang telah memberikan izin dan dukungan data selama penelitian ini.

\section{DAFTAR PUSTAKA}

Anonim, 2012. Bogor Aqricultur University (online) http:// repository. ipb. ac. $\mathrm{id} /$ bitstream/handel/1234567892/CO4a nl.pdf?sequence $=2$ diakses 25 Agustus 2017.

Amri, K., 2003. Budidaya Udang Windu Secara Intensif. Kiat mengatasi Permasalahan Praktis, Teknis Menyiapkan Benur, Membesarkan, Hingga Memanennya dengan Berorientasi pada Daya Dukung Lahan dan Kualitas Produksi, Agromedia Pustaka, jakarta Selatan.

Charles, A.T. 2001, Sustainable Fishery System, Backwell Scienceltd, oxford UK.

Dahuri, R.1998. Pembangunan Pertanian Berkelanjutan; Dalam Perspektif Ekonomi, Sosial dan Ekologi, Agrimedia Volume 4.
Dinas Perikanan Kabupaten Pinrang, 2017, Laporan Kinirja Instansi Pemerintah. Pinrang.

Fattah, M.H,, M. Saenong, Junandang, Asbar, and S.R. Busaeri, 2013 ${ }^{\mathrm{c}}$ Production of endemic Microcrustacea Phronima Suppa (Phronima sp) to Subtitude Artemia salinus in Tiger Prawn Cultivation Submitted in Journal of Applied Aquaculture.

Fattah, M.H. dan R. Busaeri, 2003. Perubahan Perilaku Manajerial PetaniI Penerima Bantuan Saluran Tambak . Jurnal Imiah Mutiara Perikanan dan Ilmu Kelautan 2 : 12 23

\section{GESAMP (IMO/FAO/UNESCO-} IOC/WMO/WHO/IAEA/UN/UNEP, Jint Group of Experts on the Scientific Aspects Of Marine Envoromental Protenction), 2001 Planning and Management for Sustainable Coastal Aquacultur Development,

Kepmen Kelautan dan Perikanan No 2, 2007, tentang Xar.

Klein, R.N. 2012. Ecofarming ; Spring Row Crop Planting and Weed Control in Winter Wheat Stubbe. University of Nebraska, Lincoln. (Online), http://weedscience.unl.edu/extension Publications/ nebguides/g551.pdf, diakses 24 Agustus 2017.

Kordi, K. M. G. H., 2010. Budi Daya Udang laut Sistem Ekstensif, Sistem Semi-Intensif, Sistem Intensif, Sistem Super Intensif, Sistem Monokultur, Sistem Polikultur, Sistem Organik, Sistem 
Tebar Gilir, Sistem Tertutup, Lily Publiser, Yogyakarta.

Munasinge, M. 2002. Environmetal Economics and Sustainable Development.

Rahmawati, W. 2014. Eksport Perikanan : 15 Perusahaan Ikan Indonesia Kembali Masuki Rusia (online) http://www.bisniscom/thumb/posts/ 2014/09/28/

260640/perikanan1.jpg?w$600 \& \mathrm{~h}=400$, diakses 24 Agustus 2017.

Silva, S. D. S. 2011, BMPs and Cluster Management for Empowering Small Scale Farmers to Remain Competitive and Sustainable, (online) http:// www. scaling. up.better.managemen.for.small.holde 15/148576380.pdf diakses 25 Agustus 2017.
UNDP. 2015. Agenda Pembangunan Berkelanjutan 2030. (Online), http:// www. id. undp.org/content/indonesia/id/home/ post-2015/sdg-overview.html ,diakses 24 Agustus 2017.

World Bank, 2017. Aquacultur Zoning Site Selection and Area Management Under Ecosystem Approach to Aquacultur full document, (Online), http:// www. fao. org/3/a-i6834e.pdf, diakses 24 Agustus 2017

World Commision on Environment and Development, 1987, Our Common Future (Document A/42/427). Oxford University Press, Oxford. 